\title{
Inorganic-Organic Hybrid Nanocomposite for Biomedical Applications
}

\author{
Susanta Bera, Atanu Naskar and Sunirmal Jana* \\ CSIR-Central Glass and Ceramic Research Institute (CSIR-CGCRI), India
}

Submission: March 01, 2017; Published: March 27, 2017

"Corresponding author: Sunirmal Jana, CSIR-Central Glass and Ceramic Research Institute (CSIR-CGCRI), 196 Raja S.C. Mullick Road, Jadavpur, Kolkata 700032, India, Email: janasunirmal@hotmail.com

\section{Introduction}

Recently, inorganic-organic hybrid nanocomposites (IOHNs) have drawn special attention for their extraordinary properties and wide spread applications in diverse fields such as cell imaging, drug delivery, photothermal therapy, bio-sensing, catalysis, energy storage and conversion, gas sensing, etc. [13]. In hybrid nanocomposite, the term 'hybrid' refers to the combination of inorganic and organic components that form a single material called nanocomposite with improved/unique properties than the individual components [4]. Origin of the properties of an IOHN can found dependent upon its particle morphology in addition to the extent of interfacial/chemical interactions existed between the components [5]. An IOHN can be more advantageous than the ordinary mixture of components for several advanced applications [1-3] but some important physicochemical characteristics of IOHNS like size, composition, surface-to-volume ratio, aggregation, stability, solubility in body fluid etc. need to study before considering the materials for biomedical applications [6].

Among varieties of organic component for IOHNs, graphene is mostly recognized as one of the potential biocompatible materials because living cells can adhere and proliferate well on graphene sheets [7]. In this context, graphene oxide (G0), a compound of graphene, is highly toxic due to the presence of large numbers of oxygen functional groups which may create more toxic effect on living cells by enhancing [8] mitochondrial respiration rate through donating its available electrons and creates reactive oxygen species (ROS) but chemically converted graphene (CCG) or reduced graphene ( $\mathrm{rGO}$ ) with less ROS is biocompatible. The large surface area, unique physiochemical properties, easy functionalization with several organics like poly(ethylene glycol), chitosan, poly(propylene glycol), poly(3hydroxybutyrate) and inorganic counterparts makes CCG/rGO an ideal candidate for biomedical applications $[7,9]$. The graphene can adsorb plenty of aromatic biomolecules, makes them ideal for biosensing applications [10]. It is noted that the interaction of rGO based nanocomposite with protein can also be utilized for detection of glucose, cholesterol, haemoglobin, etc. [10].
Among the inorganic component, silica from silane chemistry is a popular material for drug/gene delivery due to its low cytotoxicity and existence of well-established bio-conjugation mechanism [11]. The porous hollow silica nanoparticles have been employed as a carrier to control the release behavior of a model drug [11]. The hollow nanospheres of $\mathrm{Fe}_{3} \mathrm{O}_{4}$ and $\alpha-\mathrm{Fe}_{2} \mathrm{O}_{3}$ can also be used as drug carrier [12]. Besides silica, hierarchical porous titania modified with $\mathrm{ZnO}$ nanorods can also be employed for biomedical applications [13]. However, the metal oxide nanoparticles are not always biocompatible. $\mathrm{ZnO}$ nanomaterials are widely used in sunscreens lotions and cosmetics due to its non-toxicity to human skin and health. Thus, $\mathrm{ZnO}$ is known to be a biocompatible material but due to its particle dissolution, the metal oxide in tissue culture medium, can show toxic effects on living cells [7]. In the process of particle dissolution, Zn2+ ions shedding can damage lysosomes, perturbs mitochondria and generates ROS. The toxicity of $\mathrm{ZnO}$ can arise due to release of $\mathrm{Zn2+}$ ions and one possible way to resist the dissolution is the functionalization by biocompatible organics such as graphene (CCG/rGO), formation of core shell structures with other metal oxide or suitable doping into the crystal lattice [7]. It is also reported that the dissolution can be prevented by polyethylene glycol capping or Fe doping $[10,14]$ The toxicity of the nanoparticles can also be mitigated [17] through their proper surface modification with graphene. Even, highly toxic nanoparticles (such as $\mathrm{CdSe} / \mathrm{ZnS}$ quantum dots) can also tag [15] with rGO for making them potential biocompatible materials. $\mathrm{Hu}$ et al. [7] reported that quantum-dots (CdSe/ $\mathrm{ZnS}$ ) tagged reduced graphene oxide nanocomposites are useful for in-situ monitored bright fluorescence imaging and photothermal therapy of living cells. We also explored the biocompatible luminescent europium incorporated $\mathrm{ZnO}$-CCG based nanocomposite synthesized by low temperature solution process for human breast cancer cells (MCF7) imaging [7]. The graphene based hybrid nanocomposites can also show excellent antibacterial property. In this respect, researchers already investigated graphene based IOHNs for antibacterial application [14]. We also [14] reported Ag incorporated ZnO-graphene 
nanocomposite for efficient antibacterial application at $6.25 \mu \mathrm{g} /$ $\mathrm{ml}$ concentration of the nanocomposite. Thus, it is believed that the advancement of research on IOHNs is enormous but their real-life biomedical applications need special attention on precise control of their chemical and physical properties.

\section{References}

1. Ge J, Lei J, Zare RN (2012) Protein-inorganic hybrid nanoflowers. Nat Nanotech 7: 428-432.

2. Kaushik A, Kumar R, Arya SK, Nair M, Malhotra BD (2015) Organicinorganic hybrid nanocomposite-based gas sensors for environmental monitoring. Chem Rev 115: 4571-4606.

3. Lin Z, Xiao Y, Yin Y, Hu W, Liu W, et al. (2014) Facile synthesis of enzymeinorganic hybrid nanoflowers and its application as a colorimetric platform for visual detection of hydrogen peroxide and phenol. ACS Appl Mater Interfaces 6(13): 10775-10782.

4. Nicole L, Rozes L, Sanchez C (2010) Integrative approaches to hybrid multifunctional materials: From multidisciplinary research to applied technologies. Adv Mater 22(29): 3208-3214.

5. Drisko GL, Sanchez C (2012) Hybridization in materials scienceEvolution, current State, and future aspirations. Eur J Inorg Chem 2012: 5097-5105.

6. Navya PN, Daima HK (2016) Rational engineering of physicochemical properties of nanomaterials for biomedical applications with nanotoxicological perspectives. Nano Convergence 3: 1 .

7. Bera S, Ghosh M, Pal M, Das N, Saha S, et al. (2014) Synthesis, characterization and cytotoxicity of europium incorporated $\mathrm{ZnO}$ graphene nanocomposites on human MCF7 breast cancer cells. RSC Adv 4: 37479-37490.
8. Duch MC, Budinger GRS, Liang YT, Soberanes S, Urich D, et al. (2011) Minimizing oxidation and stable nanoscale dispersion improves the biocompatibility of graphene in the Lung. Nano Lett 11(12): 52015207.

9. Naskar A, Bera S, Bhattacharya R, Roy SS, Jana S (2016) Synthesis, characterization and cytotoxicity of polyethylene glycol coupled zinc oxide-chemically converted graphene nanocomposite on human OAW42 ovarian cancer cells. Polym Adv Technol 27: 436-443.

10. Pattnaik S, Swain K, Lin Z (2016) Graphene and graphene-based nanocomposites: biomedical applications and biosafety. J Mater Chem B 48(4): 7813-7831.

11. Dai L, Zhang Q, Li J, Shen X, Mu C (2015) Dendrimer like mesoporous silica nanoparticles as $\mathrm{pH}$-responsive nanocontainers for targeted drug delivery and bioimaging. ACS Appl Mater Interfaces 7(13): 73577372 .

12. Cao SW, Zhu YJ, Ma MY, Li L, Zhang L (2008) Hierarchically nanostructured magnetic hollow spheres of $\mathrm{Fe} 304$ and $\alpha-\mathrm{Fe}_{2} \mathrm{O}_{3}$ : Preparation and potential application in drug delivery. J PhysChem C 112(6): 1851-1856.

13. Chu CL, Liu ZH, Rao X, Sun Q, Lin PH, et al. (2013) Micro-nano hierarchical porous titania modified with $\mathrm{ZnO}$ nanorods for biomedical applications. Surf Coat Tech 232: 68-74.

14. Naskar A, Bera S, Bhattacharya R, Saha P, Roy SS, et al. (2016) Synthesis, characterization and antibacterial activity of Ag incorporated $\mathrm{ZnO}-$ graphene nanocomposites. RSC Adv 91(6): 88751-88761.

15. Hu SH, Chen YW, Hung WT, Chen IW, Chen SY (2012) Quantumdot-tagged reduced graphene oxide nanocomposites for bright fluorescence bioimaging and photothermal therapy monitored in situ. Adv Mater 24(13): 1748-1754.

\section{Your next submission with Juniper Publishers} will reach you the below assets

- Quality Editorial service

- Swift Peer Review

- Reprints availability

- E-prints Service

- Manuscript Podcast for convenient understanding

- Global attainment for your research

- Manuscript accessibility in different formats

( Pdf, E-pub, Full Text, Audio)

- Unceasing customer service

Track the below URL for one-step submission https://juniperpublishers.com/online-submission.php 